\title{
Does Entrepreneurship Make You Happier? A Comparative Analysis between Entrepreneurs and Wage Earners
}

\author{
Rafael Ravina-Ripoll ${ }^{1, *(\mathbb{D}}$, María-José Foncubierta-Rodríguez ${ }^{2}$, , Eduardo Ahumada-Tello $^{3}$ (1) \\ and Luis Bayardo Tobar-Pesantez ${ }^{4}$ \\ 1 Business Organization Department and INDESS, Universidad de Cádiz, Avd. de la Universidad, $n^{\circ} 4$, \\ 11406 Jerez de la Frontera, Spain \\ 2 Business Organization Department and INDESS, Universidad de Cádiz, Avd. Ramón Puyol, s/n, \\ 11202 Algeciras, Spain; mariajose.foncubierta@uca.es \\ 3 Accountancy and Administration, Universidad Autónoma de Baja California, Calzada Universidad 14418, \\ Mesa de Otay, Tijuana 22390, Mexico; eahumada@uabc.edu.mx \\ 4 Carrera de Economía, Universidad Politécnica Salesiana, Cuenca 010105, Ecuador; ltobar@ups.edu.ec \\ * Correspondence: rafael.ravina@uca.es
}

check for

updates

Citation: Ravina-Ripoll, R.; Foncubierta-Rodríguez, M.-J.; Ahumada-Tello, E.; Tobar-Pesantez, L.B. Does Entrepreneurship Make You Happier? A Comparative Analysis between Entrepreneurs and Wage Earners. Sustainability 2021, 13, 9997. https://doi.org/10.3390/ su13189997

Academic Editor:

Manuela Tvaronaviciene

Received: 6 August 2021

Accepted: 31 August 2021

Published: 7 September 2021

Publisher's Note: MDPI stays neutral with regard to jurisdictional claims in published maps and institutional affiliations.

Copyright: (C) 2021 by the authors. Licensee MDPI, Basel, Switzerland. This article is an open access article distributed under the terms and conditions of the Creative Commons Attribution (CC BY) license (https:/ / creativecommons.org/licenses/by/ $4.0 /)$.

\begin{abstract}
Currently, age is characterized by implementing business management models based on precarious work and a massive reduction in jobs. This article aims to analyze the degree of happiness perceived in Spanish entrepreneurs, as opposed to that perceived by the employees, and if that happiness is associated with certain sociodemographic variables (such as gender, level of studies, and income level). For this purpose, a brief literature review of the economy of happiness is carried out, considering studies regarding the happiness-entrepreneurship connection over the past few years. With data provided by the Sociological Research Center (C.I.S.) barometer survey, we work in two phases: (1) descriptive and inferential on possible associations between the variables, and (2) the calculation of probabilities through logistic regression. The main result shows that the entrepreneurs with employees are happiest. When the null hypothesis is rejected, the categories that seem to show the most happiness are those with higher education and those in the highest income ranges analyzed. Among the main limitations in this work is the scarcity of bibliographic production on the subject matter of this paper. This paper helps to cover part of this gap.
\end{abstract}

Keywords: well-being; entrepreneurship; entrepreneur; wage earner

\section{Introduction and Conceptual Background}

Over the past five years, many researchers have carried out numerous studies exploring the holistic relationship between entrepreneurs/the self-employed and well-being [1-4]. As a common denominator, many of these investigations contextualize the term well-being as synonymous with happiness and quality of life [5-8]. From this theoretical starting point, a body of literature evaluates which personal attributes and socioeconomic factors have notable and consistent correlations with people's subjective well-being. Entrepreneurs are one of the groups that contribute most to the diversification and prosperity of productive ecosystems. Entrepreneurs also contribute to enriching citizens' quality of life in a digital society through the daily activity of their businesses and are not isolated from this scientific reality [9].

Until recently, studies on entrepreneurs' happiness have focused on analyzing the influence of health parameters, gender, prosocial motivation, or job satisfaction on their subjective state of well-being [10-13]. Such studies have also tried to show that entrepreneurs or self-employed individuals are generally happier than salaried people in terms of the daily performance of their jobs [14]. However, few multidisciplinary studies empirically explore whether happiness leads individuals to be future technological entrepreneurs or consider other new opportunities [15]. 
In our view, the development of this type of work will be noteworthy when considering the happiness of this human capital as a strategic element that facilitates the creation of innovative and high-quality products or services [16]. This information will be beneficial to show political leaders involved in public administration that, through the cultivation of entrepreneurs' happiness, it is possible to promote the integral development of the urban and rural landscapes [17]. Such developments can facilitate the compatibility of economic competitiveness with social well-being and sustainability $[18,19]$. This research will better answer the following questions: What sociodemographic factors lead individuals to be happy entrepreneurs? Does the entrepreneurial spirit of individuals have a role in improving the status of their psychological and economic happiness? How can the social value generated by happy entrepreneurs be measured?

Finally, we would like to point out that the purpose of this article is to contribute to the existing academic literature on the happiness of Spanish entrepreneurs. Three aspects mainly justify the choice of Spain as a research scenario. First, because it is the European Union territory with the highest youth unemployment rate, this would seem to favor entrepreneurship. Secondly, Spain has a unique labor market characterized by one of the lowest rates of opportunity entrepreneurship among the most advanced nations in the world during the first two decades of the 21st century. Thirdly, Spain has a European tax system that makes creating new entrepreneurs difficult [20]. We hope to help fill the current research gap on happiness, creativity, and intellectual capital [21].

In light of the literature reviewed for the development of this study, there has been no definition of the term entrepreneur or self-employed individual between the years 1950 and 2019 that even remotely considers the fact that the motivational factor of happiness is powerfully relevant in a holistic sense and can induce human beings to be academic, social or opportunity-based entrepreneurs [22-26]. However, extensive literature relates the concepts of welfare or happiness - understood in a hedonic or eudaimonic way-with entrepreneurs, entrepreneurship, or the entrepreneurial spirit [23-37].

In this regard, it should be noted that some of these studies have been devoted to empirically demonstrating that entrepreneurs who have low levels of income at the beginning of their business activity tend to experience a greater degree of happiness when they are focused exclusively on noneconomic objectives [32-34]. However, multiple other studies have focused on findings indicating that entrepreneurs tend to have a higher rate of happiness than the average groups found in medium and large businesses [35]. It is because entrepreneurs are very satisfied with the performance of their job. After all, they have a high degree of professional freedom to make decisions linked to the strategic direction of their organizations [36-38].

Therefore, the first hypothesis to be established would be a general hypothesis about the different perceptions of happiness among the different professional categories or situations of the population:

$\mathrm{H}_{1}$. There is a relationship between the type of professional situation (employee, businessperson, self-employed, cooperative, etc.) and happiness; that is, there is an association between the different employment categories (represented by the variable professional situation) and the value given to the variable that measures the degree of perceived happiness [39]. The averages of the distributions for each category are not similar [40]. In the case of entrepreneurs, and according to what is reflected in the literature, this could be summed up as follows:

$\mathrm{H}_{2}$. There is a relationship between being an entrepreneur and feeling happier; there is an association between having one's own business and the variable's values that measure the degree of perceived happiness [41].

On the other hand, extensive bibliographical production of theoretical and statistical work estimates that the happiness of individuals does not depend exclusively on the economic and political situation of the geographical area. The happiness of individuals depends on other elements of a different nature, such as sociodemographic factors [42-49]. The variables of gender and education should also be considered [50]. 
A review of the literature concerning how the demographic factors cited above impact people's happiness and subjective well-being shows us that women are happier than men [51-54] and that the level of education does not have a direct impact on the happiness of the inhabitants of the most advanced countries [55-57].

If, as the literature suggests, there is an association between these variables, that is, the null hypothesis for the group of entrepreneurs is rejected, the hypotheses would be proposed for entrepreneurs with a specific profile or sociodemographic characteristics, such as gender, level of studies and income level, to analyze whether the happiness of the entrepreneur is associated with the various categories that may be adopted [58,59].

$\mathrm{H}_{1 \mathrm{EmpSex}}$. There is a relationship between the gender of the entrepreneur and the degree of happiness he/she perceives. An association is produced between the category representing the variable sex and the value given to the variable that measures the degree of happiness; the averages of the distributions are not similar, and its corresponding null hypothesis $\left(\mathrm{H}_{0 \text { EmpSex. }}\right.$ )

Similarly, the pairs of hypotheses to be contrasted that relate to the variable of studies, level of income, and the degree of happiness are analyzed $\left(\mathrm{H}_{1 \text { EmpStud }}\right.$ and $\left.\mathrm{H}_{1 \text { EmpInc }}\right)$. The same hypotheses would be proposed for the categories of permanent employees and temporary employees, allowing comparison [60].

However, this reality has not yet been statistically confirmed in Spain. Among the different reasons for this shortfall in research is the scarcity of studies on the subjective well-being of Spanish entrepreneurs [18]. It entails the absence of research dedicated to exploring how sociodemographic factors influence the happiness of these economic agents during the first years of this century [61].

This article originated with the desire to contribute to empirical research on this scientific construct [59] in general, and to fill this gap in the entrepreneurial population in Spain in particular, as well as the idea of recognizing the happiness variable as an intangible resource that has tremendous importance in people's will to be future social, academic or opportunity-based entrepreneurs [62].

\section{Materials and Methods}

The data recorded in the Barometer of the Centro de Investigaciones Sociológicas (C.I.S.) in September 2018 were used to carry out this work. The C.I.S. is a nationwide Sociological Research Center study in Spain with a sample of 2972 records of adults of both sexes. The data cover 292 municipalities in 50 provinces. The sampling was done with stratified sampling clusters; municipalities were the primary units, and sections were used as secondary units (in a proportionally altered way). Finally, the individuals within these units were identified by random sampling with age and gender quotas considered. The sampling error was $\pm 1.8 \%$ for the entire sample with a $95.5 \%$ (two sigma) and $p=q$ confidence level. The method chosen to test the opinion of the respondents was a questionnaire [63]. This was administered through in-person home interviews.

The aim was to analyze the degree of happiness perceived in the group of Spanish entrepreneurs (either with or without employees), compared to that perceived by employees (whether permanent or temporary), and if that happiness is associated with certain sociodemographic variables thereof (such as sex, level of studies and income level).

In this study, entrepreneurs are understood as those in categories 3 and 4 of the variable Employment relations (P38) of the questionnaire: entrepreneur or professional with employees and professional or self-employed without employees. The measure of happiness is measured by question P6: "Generally, to what extent do you consider yourself a happy or unhappy person?" The responses are measured using a Likert scale in which 0 means "completely unhappy" and ten means "completely happy"; 5 is an average or neutral value that could be interpreted as "neither happy nor unhappy" [64]. The sociodemographic profile variables to be used are sex (P30), level of studies (P32a), and income level (P41) (Table 1). 
Table 1. Variables in the research.

\begin{tabular}{|c|c|c|c|}
\hline Variables Used & $\begin{array}{l}\text { Question N'. C.I.S. } \\
\text { Barometer, Sept } 2018\end{array}$ & Questionnaire Item & Rank \\
\hline $\begin{array}{l}\text { Professional situation: } \\
\text { entrepreneurs }\end{array}$ & P38 & $\begin{array}{l}\text { Professional situation of the } \\
\text { participant }\end{array}$ & $\begin{array}{l}\text { 1: Fixed-salary employees (by salary, } \\
\text { commission, wage, etc., with a fixed } \\
\text { character). } \\
\text { 2: Temporary employees (by salary, } \\
\text { commission, wage, etc., temporary or } \\
\text { interim). } \\
\text { 3: Entrepreneur or professional with } \\
\text { employees. } \\
\text { 4. Professional or self-employed worker } \\
\text { (without employees). } \\
\text { 5: Family assistance (without regulated } \\
\text { remuneration in a family member's } \\
\text { business). } \\
\text { 6: Member of a cooperative. } \\
\text { 7. Another situation. }\end{array}$ \\
\hline Gender & P30 & Gender & $\begin{array}{l}\text { 1: Male } \\
\text { 2: Female }\end{array}$ \\
\hline Level of studies & P32a & $\begin{array}{l}\text { What are the highest-level } \\
\text { official studies that you have } \\
\text { taken? }\end{array}$ & $\begin{array}{l}0 \text { : Less than five years of schooling. } \\
\text { 14: University postgraduate degrees. }\end{array}$ \\
\hline Income level & P41 & $\begin{array}{l}\text { In which section is your } \\
\text { personal income, after-tax } \\
\text { deductions, that is to say, } \\
\text { your net income? }\end{array}$ & $\begin{array}{l}\text { 1: You have no income of any kind. } \\
\text { 2: Less than or equal to EUR } 300 . \\
\text { 3: From } 301 \text { to EUR } 600 . \\
\text { 4: From } 601 \text { to EUR } 900 . \\
\text { 5: From } 901 \text { to EUR } 1200 \text {. } \\
\text { 6: From } 1201 \text { to EUR } 1800 \text {. } \\
\text { 7: From } 1801 \text { to EUR } 2400 \text {. } \\
\text { 8: From } 2401 \text { to EUR } 3000 \text {. } \\
\text { 9: From } 3001 \text { to EUR } 4500 . \\
\text { 10: From } 4501 \text { to EUR } 6000 \text {. } \\
\text { 11: More than EUR } 6000 \text {. }\end{array}$ \\
\hline Degree of Happiness & P6 & $\begin{array}{l}\text { In general terms, to what } \\
\text { extent do you consider } \\
\text { yourself a happy or an } \\
\text { unhappy person? }\end{array}$ & $\begin{array}{l}\text { 0: Completely unhappy. } \\
\text { 10: Completely happy. }\end{array}$ \\
\hline
\end{tabular}

Source: C.I.S. (2018).

\section{Results}

In this section, the results derived from our study will be presented. The similarities or divergences with other analyses in the literature on this subject will be presented in the following section, Discussion and Conclusion.

An initial study of the overall sample will be carried out, followed by an analysis differentiating between the categories of entrepreneurs and employees.

\subsection{Overall Sample}

By refining the data and eliminating the answers DK/ND (Do not Know/Not Determined) from the variable P6 and the variable P38, a sample of 2928 records was obtained. The data were processed with IBM SPSS statistical software 27.

Categories 5, 6, and 7 are removed from the sample because they have a minimal number of records, leaving 2912 records in total: category 1 (N: 1752), category 2 (N: 613), category $3(\mathrm{~N}: 136)$ and category 4 (N: 411). 
After checking the data with the Kolmogorov-Smirnov (from now on: K-S) and Shapiro-Wilk (from now on: S-W) methods, we conclude that the data have non-normal distributions (Table 2).

Table 2. Tests for the normality of distributions for variables P6 and P38.

\begin{tabular}{cccccccc}
\hline & P38 & \multicolumn{3}{c}{ Kolmogorov-Smirnov } & \multicolumn{3}{c}{ Shapiro-Wilk } \\
\hline & Statistic & df & Sig. & Statistic & df & Sig. \\
\hline \multirow{4}{*}{ P6 } & 1 & 0.183 & 1752 & $<0.001$ & 0.906 & 1752 & $<0.001$ \\
& 2 & 0.169 & 613 & $<0.001$ & 0.908 & 613 & $<0.001$ \\
& 3 & 0.172 & 136 & $<0.001$ & 0.917 & 136 & $<0.001$ \\
& 4 & 0.169 & 411 & $<0.001$ & 0.917 & 411 & $<0.001$ \\
\hline
\end{tabular}

The table below (Table 3) shows how for each score, 6 to 10 on happiness, the ones that imply that the person feels a sense of happiness-from moderately (6) to completely (10) - are not always found in the groups of entrepreneurs. In addition to the members of cooperatives, who account for $100 \%$ of the values 6 and 10 , the highest total percentage of these values is found among entrepreneurs and professionals with employees (89.80\%) [65]. These groups are followed by professionals or self-employed without employees $(87.80 \%)$ and fixed-salary employees $(87.00 \%)$.

Table 3. Degree of happiness by category of the employment situation.

\begin{tabular}{ccccccccc}
\hline P38 & $\mathbf{N}$ & Average & Standard Desv. & \% (6 to10) & \% (7 to10) & \% (8 to10) & \% (9 to10) & \% 10 \\
\hline 1 & 1752 & 7.38 & 0.41 & 87.00 & 77.00 & 52.50 & 22.10 & 10.00 \\
2 & 613 & 7.19 & 0.76 & 83.10 & 71.00 & 49.00 & 22.40 & 9.50 \\
3 & 136 & 7.76 & 0.15 & 89.80 & 80.20 & 61.80 & 33.10 & 19.19 \\
4 & 411 & 7.40 & 0.08 & 87.80 & 75.40 & 53.00 & 23.60 & 9.70 \\
\hline
\end{tabular}

In contrast to the null hypothesis, the Kruskal-Wallis test (with sig $=0.007$, error lower than $1 \%$ ) indicates that the null hypothesis is rejected. Given the number of components in the sample and following the Law of Large Numbers, it is important to understand how the distributions behave. The Levene test indicates the similarity of variances (sig > 0.05). ANOVA ( $\operatorname{sig}=0.004$ ) is also carried out, confirming the null hypothesis's rejection [66]. However, which are the statistically different means between all P38 groups?

Figure 1 shows that it is precisely category 3, employers with employees, that offers such differences. The results of the D.M.S. post-hoc test show that these differences are:

- The averages are between category 3 (entrepreneurs or professionals with employees) and category 2 (casual employees), de 0.572 points in the averages. Sig $=0.1 \%$ error;

- Between category 3 and category 1 (fixed employees), of 0.385 points, next to $1 \%$ error;

- And between category 3 and category 4 (Professional or self-employed, without workers), de 0.363 . Sig. al 5\% de error.

How much more likely is it that an entrepreneurial person with employees (category 3 ) will be happier than the other types? To answer this question, variables P6 and P38 are transformed into dummy variables [67]. Looking at the average of category 3 (7.76) compared to the other categories of P38, the values 8,9 , and 10 would take value 1 in the dummy variable, and the rest value 0 . On the other hand, in the P38 variable, 1 is assumed for category 3 and 0 for the rest [68]. Given the interpretation of the limits of P6, values are taken from 6 , since 5 is the average value, and it would mean "neither unhappy nor happy"; therefore, beginning with 6 , the person begins to declare himself happy to various degrees. It can be understood that 6 would be moderately happy, 7 quite happy, 8 happy, 9 very happy, and 10 completely happy [69]. In these cases, logistic regression is applied after transforming the variable P6 into a dichotomous variable (Table 4) [70]. 


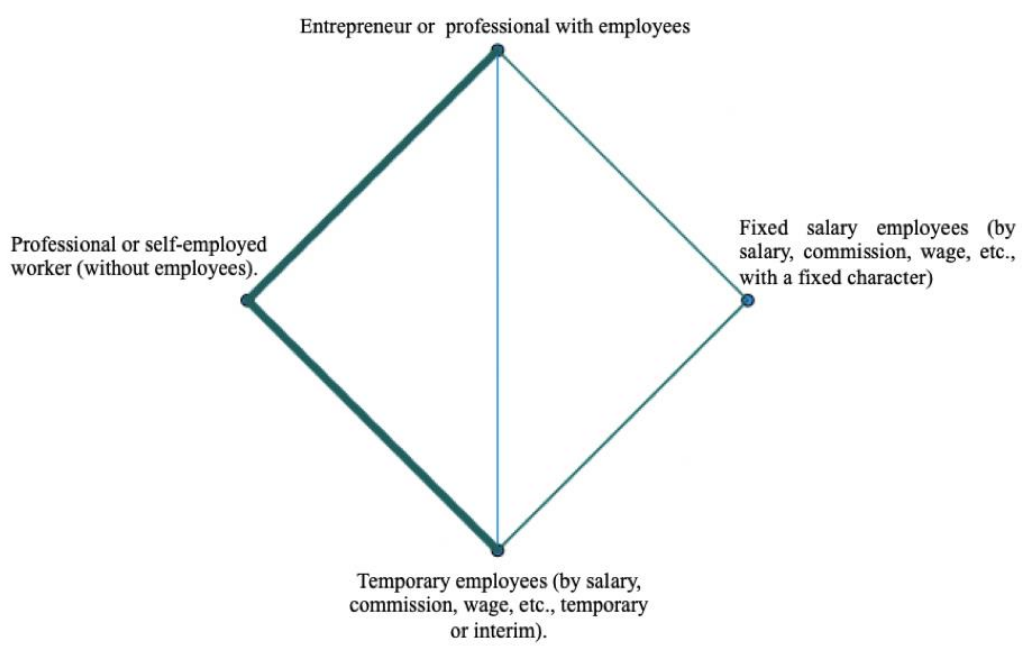

\begin{tabular}{ll}
\hline \multicolumn{1}{|c}{ Sample 1 Sample 2 } & Sig. \\
\hline 2 compared to 1 & 0.059 \\
\hline 2 compared to 4 & 0.127 \\
\hline 2 compared to 3 & 0.001 \\
\hline 1 compared to 4 & 0.876 \\
\hline 1 compared to 3 & 0.009 \\
\hline 4 compared to 3 & 0.023 \\
\hline
\end{tabular}

Figure 1. Pair comparisons between categories of P38. Note: Each row tests the null hypothesis that the distributions in Sample 1 and Sample 2 are equal. Asymptotic meanings (bilateral tests) are displayed. The significance level is 0.050 .

Table 4. Relationship between perceived happiness and professional situation. Comparison of the entrepreneur with employee's category and the other categories.

\begin{tabular}{|c|c|c|c|c|c|c|}
\hline \multicolumn{7}{|c|}{ Comparison P38 = 3 with P38 = 2} \\
\hline & & & \multicolumn{2}{|c|}{ Confidence Interval 95\% } & \multicolumn{2}{|c|}{ Value Forecast } \\
\hline Degree of Happiness & Sig. & $\operatorname{Exp}(B)$ & Inferior & Superior & $\begin{array}{c}\text { For P6 = } 0 \\
\text { (specificity) }\end{array}$ & $\begin{array}{c}\text { For } 6=1 \\
\text { (sensibility) }\end{array}$ \\
\hline \multirow{2}{*}{ Values between 8 and 10} & \multirow{2}{*}{0.007} & \multirow{2}{*}{1.686} & \multirow{2}{*}{0.406} & \multirow{2}{*}{0.868} & $85.80 \%$ & $21.90 \%$ \\
\hline & & & & & \multicolumn{2}{|c|}{$53.00 \%$} \\
\hline \multicolumn{7}{|c|}{ Comparison P38 = 3 with P38 = 1} \\
\hline \multirow{2}{*}{ Values between 8 and10 } & \multirow{2}{*}{0.039} & \multirow[b]{2}{*}{1.458} & \multirow{2}{*}{0.479} & \multirow[b]{2}{*}{0.982} & $0 \%$ & $100 \%$ \\
\hline & & & & & \multicolumn{2}{|c|}{$53.2 \%$} \\
\hline \multicolumn{7}{|c|}{ Comparison P38 = 3 with P38 = 4} \\
\hline \multirow{2}{*}{ Values between 9 and 10} & \multirow{2}{*}{0.029} & \multirow{2}{*}{1.601} & \multirow{2}{*}{1.048} & \multirow{2}{*}{2.445} & $100 \%$ & $0 \%$ \\
\hline & & & & & \multicolumn{2}{|c|}{$74 \%$} \\
\hline \multicolumn{7}{|c|}{ Comparison P38 = 3 with P38 $\neq 3$} \\
\hline \multirow{2}{*}{ Values between 8 and 10} & \multirow{2}{*}{0.024} & \multirow{2}{*}{1.501} & \multirow{2}{*}{0.468} & \multirow{2}{*}{0.949} & $0 \%$ & $100 \%$ \\
\hline & & & & & \multicolumn{2}{|c|}{$52.3 \%$} \\
\hline \multirow{2}{*}{ Values between 9 and 10} & \multirow{2}{*}{0.004} & \multirow{2}{*}{1.712} & \multirow{2}{*}{0.404} & \multirow{2}{*}{0.844} & $100 \%$ & $0 \%$ \\
\hline & & & & & \multicolumn{2}{|c|}{$77.1 \%$} \\
\hline \multirow{2}{*}{ Value 10} & - & 2160 & (207 & 0723 & $100 \%$ & $0 \%$ \\
\hline & $<0.001$ & 2.100 & 0.297 & 0.720 & & \\
\hline
\end{tabular}


The O.D.D.s ratios, or Ex (B), obtained are close to 2, i.e., double the probabilities when dealing with entrepreneurs with employees. Thus, in the comparison between categories 3 and 2, the likelihood of an employer with employees feeling happy to completely happy would be 1.686 times that of a casual employee; and 1.458 times that of a permanent employee [71]. In the case of professionals that are self-employed without employees, only when P6 values of 9 to 10 have been taken (making the dummy variable zero at the value 8 as well) is a sign of less than 5\% error given, resulting in an employer with employees feeling from very happy to completely happy with 1.601 times more probability than an employer without employees [72].

The O.D.D. ratio exceeds 2 when comparing being an employer with employees with the rest of the categories. In feeling completely happy, an employer with employees is 2.16 times more likely to feel this way than anyone in the other professional categories [73].

The confidence interval contains unity in none of the cases studied in this regression analysis [74]. However, the specificities and sensitivities of the theoretical prediction model are not balanced, as they are found in pairs of $0 \%-100 \%$ or $100 \%-0 \%$. Only in the first case studied/analyzed are they moderated, with a specificity of $85.8 \%$, a sensitivity of $21.9 \%$, and, in general, 53\% of the model fit [75].

\subsection{Category Samples}

A general linear model is employed to evaluate the variables P6 and P30 to check the interaction between the two variables. The results indicate that, in the sample as a whole, there will be no relationship between the variables P6 and P30, the one corresponding to gender [76]. Indeed, their distributions are, for the most part, nonparametric. Both the Mann-Whitney test (0.475) and Student t-test (0.285) show that there are no statistically significant differences [77].

In the category of employers with employees, there is no statistically significant difference between men and women. Nor is there one among permanent employees. There is a statistically significant difference between men and women who are temporary employees: women report being the happiest (although the Spearman correlation is very low, 8\%) [78]. There are also statistically significant differences between men and women in category 4, employers without employees; in this case, men (average 7.59) seem to be happier than women (average 7.23), with a Spearman correlation of 10.3\% (Table 5) [79].

Table 5. Parameters for the relationship between perceived happiness and gender by the professional situation.

\begin{tabular}{|c|c|c|c|c|c|c|c|c|}
\hline \multicolumn{9}{|c|}{ Category 3} \\
\hline & & P6 & P30 & & P6 & P30 & Mann-Whitney & $t$-Student \\
\hline \multirow[b]{2}{*}{ P6 } & Spearman & 1 & -0.143 & Pearson & 1 & -0.147 & $p=0.097$ & $p=0.087$ \\
\hline & Sig. (bilat.) & & 0.097 & Sig. (bilat.) & & 0.087 & $\begin{array}{c}\text { Man } \\
\text { mean }(\mathrm{dev}) \\
7.94(0.171)\end{array}$ & $\begin{array}{c}\text { Woman } \\
\text { mean (dev) } \\
7.40(0.277)\end{array}$ \\
\hline \multicolumn{9}{|c|}{ Category 4} \\
\hline \multirow{2}{*}{ P6 } & Spearman & 1 & $-0.103 *$ & Pearson & 1 & $-0.106^{*}$ & $p=0.037$ & $p=0.032$ \\
\hline & Sig. (bilat.) & & 0.037 & Sig. (bilat.) & & 0.032 & $7.59(0.115)$ & $7.23(0.119)$ \\
\hline \multicolumn{9}{|c|}{ Category 1} \\
\hline \multirow{2}{*}{ P6 } & Spearman & 1 & -0.007 & Pearson & 1 & -0.017 & $p=0.078$ & $p=0.483$ \\
\hline & Sig. (bilat.) & & 0.780 & Sig. (bilat.) & & 0.483 & $7.41(0.057)$ & $7.35(0.059)$ \\
\hline \multicolumn{9}{|c|}{ Category 2} \\
\hline \multirow{2}{*}{ P6 } & Spearman & 1 & 0.080 * & Pearson & 1 & 0.071 & $p=0.047$ & $p=0.080$ \\
\hline & Sig. (bilat.) & & 0.047 & Sig. (bilat.) & & 0.080 & $7.05(0.116)$ & $7.32(0.101)$ \\
\hline
\end{tabular}


The educational level, variable P32a in the C.I.S. study, has 14 categories corresponding to the different academic levels in the Spanish system. In this work, these categories have been added to resemble the homogeneous categorization at the international level, knowing that some details in the original information are lost in this process. In this way, the registration number is also more significant for each level [80]. Category 1 will now be the sum of category 0 (Less than 5 years of schooling) with category 1 (Primary Studies) [81].

Category 2, Secondary Studies, in the C.I.S. survey corresponds to a Professional Education at the initial level, Secondary Education, Professional Education medium level, 2 more years in high school and Professional Education superior level (categories 2, 3, 4, 5 and 6); category 3, Level 1 University Studies, corresponds to Architecture or technical engineering studies, a College Diploma and Graduate Studies (categories 7, 8 y 9); and category 4, Level 2 University Studies, corresponds to Undergraduate Studies, Architecture or higher engineering studies, Official University master's degree, and Ph.D. and University postgraduate degrees (categories 10 to 14) [82].

At the whole sample level, there is a relationship between both variables, P6 and P32a (Kruskal-Wallis and ANOVA tests: $\operatorname{sig}=<0.001$ ). Most of the distributions are not expected. According to the Levene test, the variances are not homogeneous, so an intergroup post-hoc comparison is carried out using the Games-Howell test. Significant intergroup differences appear in group 4-university level 2-(on average 7.66), with groups 0 , less than 5 years of study (with average 6.99), 1, primary (with average 7.26), and 2, secondary (average 7.26); and group 3-university level 1-(on average 7.53), with group 1, primary studies [83]. It is verified that, in both cases, people belonging to the university groups show higher levels of happiness [84].

When analyzed by categories of professional situations, most of the distributions are not expected in all cases. Spearman's and Pearson's correlations, means, and standard deviations, as well as the parameters of the Kruskal-Wallis test and ANOVA test, are shown in Table 6 [85].

Table 6. Parameters on the relationship between perceived happiness and educational level according to professional situation.

\begin{tabular}{|c|c|c|c|c|c|c|c|c|}
\hline \multicolumn{9}{|c|}{ Category 3} \\
\hline & & P6 & P32a & & P6 & P32a & Kruskal-Wallis & ANOVA \\
\hline \multirow{2}{*}{ P6 } & Spearman & 1 & -0.091 & Pearson & 1 & -0.042 & \multirow{2}{*}{$p=0.399$} & \multirow{2}{*}{$p=0.563$} \\
\hline & Sig. (bilat.) & & 0.294 & Sig. (bilat.) & & 0.629 & & \\
\hline \multicolumn{9}{|c|}{ Category 4} \\
\hline \multirow{2}{*}{ P6 } & Spearman & 1 & $0.117 *$ & Pearson & 1 & 0.114 * & Kruskal-Wallis & ANOVA \\
\hline & Sig. (bilat.) & & 0.017 & Sig. (bilat.) & & 0.021 & $p=0.090$ & $p=0.084$ \\
\hline \multicolumn{9}{|c|}{ Category 1} \\
\hline \multirow[t]{2}{*}{ P6 } & Spearman & 1 & $0.090^{* *}$ & Pearson & 1 & $0.089 * *$ & Kruskal-Wallis & $\begin{array}{c}\text { ANOVA } \\
\text { (Welch/ } \\
\text { Brown-Forsythe) }\end{array}$ \\
\hline & Sig. (bilat.) & & $<0.001$ & Sig. (bilat.) & & $<0.001$ & $p=<0.001$ & $p=(<0.001 /<0.001)$ \\
\hline \multicolumn{9}{|c|}{ Category 2} \\
\hline \multirow[t]{2}{*}{ P6 } & Spearman & 1 & $0.176^{* *}$ & Pearson & 1 & $0.173^{* *}$ & Kruskal-Wallis & $\begin{array}{c}\text { ANOVA } \\
\text { (Welch/ } \\
\text { Brown-Forsythe) }\end{array}$ \\
\hline & Sig. (bilat.) & & $<0.001$ & Sig. (bilat.) & & $<0.001$ & $p=<0.001$ & $p=(<0.001 /<0.001)$ \\
\hline
\end{tabular}

\footnotetext{
${ }^{*}$ Correlation is significant at the 0.05 level (bilateral). ${ }^{* *}$ Correlation is significant at the 0.001 level (bilateral).
} 
Regarding the correlations:

- $\quad$ For P38 $=3$, it is negative, very weak, and not significant $(p>0.05)$.

- For P38 $=4$, it is positive, weak, and significant, but only at the $5 \%$ error level. It can give guarantees that as the sample increases, this correlation does not vary significantly.

- For P38 $=1$, it is positive, fragile, but significant at the $1 \%$ error level. In this case, the sample is the largest of all the categories, which would help to ensure that a similar correlation is maintained as it increases.

- For $38=2$, it is positive, the highest of all correlations. However, it does not even reach $20 \%$, and it has an error level significance of $1 \%$. The sample size is also considerable, so a similar level of correlation could be guaranteed in other samples higher in number [86].

As expected, Pearson's parameters are similar and would lead to the same reflections in all of them.

In the null hypothesis contrast analysis, a nonparametric test of Kruskal-Wallis and ANOVA test is used. However, robust tests are used when the Levene test confirms no similarity of variances (Welch and Brown-Forsythe). The results show that:

- For the group of entrepreneurs with employees, there is no statistically significant difference between the categories of educational levels.

- In the group of professionals and self-employed without employees, there are no statistically significant differences between the means of the different levels of education neither.

- For permanent employee's, significance appears $(p<0.1 \%)$. According to the Levene test, the variances are not equal, so the Games-Howell multiple comparison tests are used. The results indicate that differences with significance at the $0.1 \%$ level occur between levels 3 , the first level of university degree (7.68 on average), and level 1 , up to primary studies (average 6.87), and between level 3 and level 2 (secondary studies, average 7.28 ). The difference with significance at the $5 \%$ level occurs between educational level 1 and level 4, the second level of university degree (average 7.51) (Figure 2).

- It is also true for the group of temporary employees. In this case, there is no equality of variances either. The Games-Howell test shows that significant intergroup differences lower than $0.1 \%$ error exists between group 4 (mean 7.90 ) and group 1 (6.67 average) and group 4 and group 2, secondary studies (average 7.04). For an error lower than $5 \%$, differences exist between category 3 (average 7.46) and category 1 ; and category 3 and category 2 (Figure 2) [87].

When the economic income variable P41 is studied, category 1 is maintained, without income; category 2 is formed by the aggregation of 2,3, and 4, becoming the range from 1 to 900 euros; category 3 is formed by the aggregation of 5 and 6 , constituting the range from 901 to 1800 euros; category 4 comprises $7,8,9,10$, and 11, more than 1800 euros.

If the sample is taken together, the distributions are all not normal. The Spearman correlation is positive but weak $(7.2 \%)$ and significant at $0.1 \%(\mathrm{sig}=0.001)$. The Pearson coefficient is also positive and weak $(4.9 \%)$, with statistical significance at $5 \%(\operatorname{sig}=0.025)$. The null hypothesis is rejected since both the Kruskal-Wallis and ANOVA tests have sig $<0.001$. The Levene test confirms that the variances are not homogeneous. Multiple inter-category comparisons are performed through the Games-Howell test. This test indicates that the differences with statistical significance are those that occur between category 2 (mean 7.01) and categories 1 (mean 7.41), 3 (mean 7.52), and 4 (mean 7.61)-that is, people who earn between 1 and 900 euros seem to be the least happy. 


\section{Category 1}

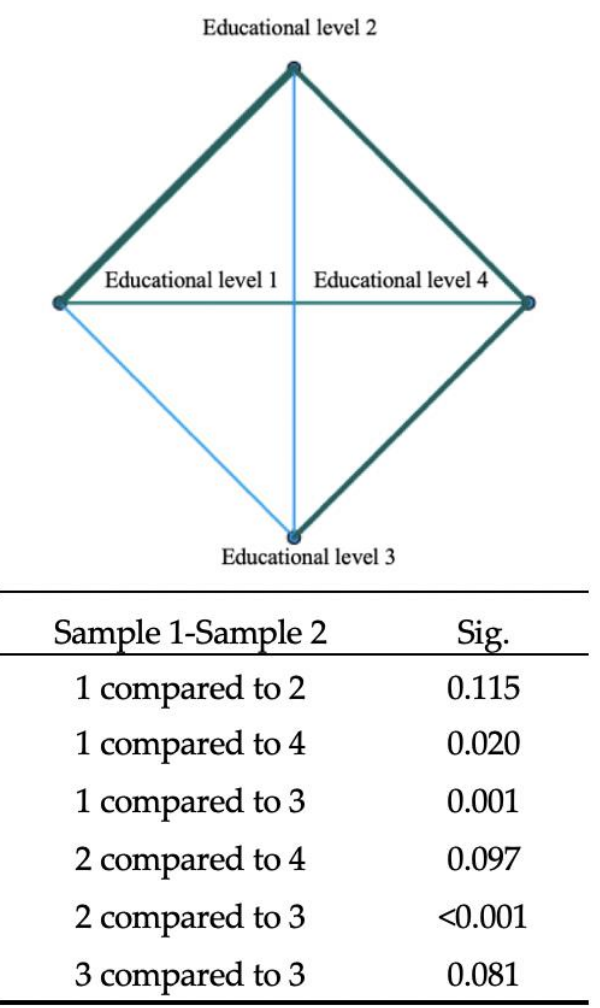

Category 2

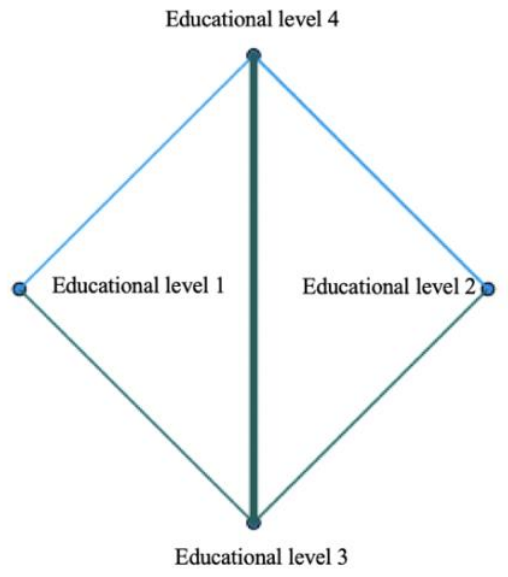

\begin{tabular}{cc}
\hline Sample 1-Sample 2 & Sig. \\
\hline 1 compared to 2 & 0.203 \\
1 compared to 3 & 0.021 \\
1 compared to 4 & 0.001 \\
2 compared to 3 & 0.045 \\
2 compared to 4 & $<0.001$ \\
4 compared to 4 & 0.130 \\
\hline
\end{tabular}

Figure 2. Pair comparisons between categories of educational levels in P38 = 1 and P38 = 2. Note: Each row tests the null hypothesis that the distributions in Sample 1 and Sample 2 are equal. Asymptotic meanings (bilateral tests) are displayed. The significance level is 0.050 .

When the analysis by professional category is carried out, correlations, means, standard deviations, and the parameters of the Kruskal-Wallis test and ANOVA test (or robust tests of Welch and Brown-Forsythe) are shown in Table 7.

- $\quad$ For $\mathrm{P} 38=3$, it is positive, fragile, and not significant $(p>0.05)$.

- For P38 $=4$, it is positive, weak, but significant at the $5 \%$ error level in the Spearman test.

- For P38 $=1$, it is positive, fragile, and not significant.

- $\quad$ or $38=2$, it is positive, the highest of all. However, it does not even reach $20 \%$, and it has an error level significance lower than $0.1 \%$.

When comparing the null hypothesis's contrast between entrepreneurs and employees, Kruskal-Wallis and robust tests confirm no relationship between the variables. In the category of entrepreneurs without employees (Kruskal-Wallis: 0.014 and robust test: $<0.001$ ), in the category of permanent employees (Kruskal-Wallis and robust tests: <0.001) and in the category of temporary employees (Kruskal-Wallis: 0.007 and robust tests: $<0.001)$, there is a relationship between the two variables. In all three cases, the variances are not homogeneous, according to the Levene indicator, so the Games-Howell multiple comparison tests are used to determine the significant differences between the different categories of P41 (Figure 3). 
Category 4

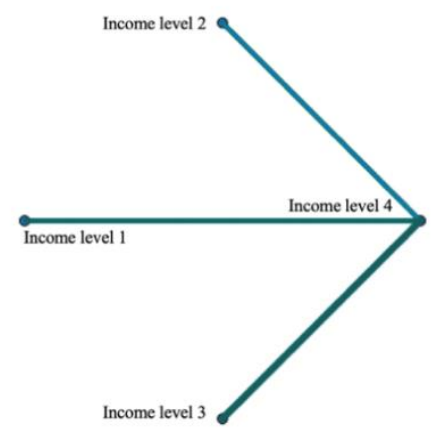

\begin{tabular}{cc}
\hline Sample 1-Sample 2 & Sig. \\
\hline 2 compared to 1 & 0.307 \\
2 compared to 3 & 0.184 \\
2 compared to 4 & 0.001 \\
1 compared to 3 & 0.821 \\
1 compared to 4 & 0.028 \\
3 compared to 4 & 0.039 \\
\hline
\end{tabular}

Category 1

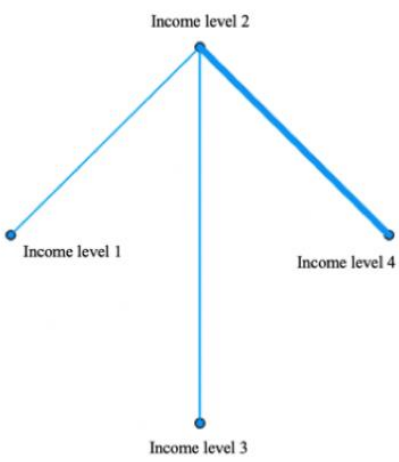

\begin{tabular}{lr}
\hline Sample 1-Sample 2 & \multicolumn{1}{c}{ Sig. } \\
\hline 2 compared to 3 & $<0.001$ \\
2 compared to 4 & 0,001 \\
2 compared to 1 & $<0.001$ \\
3 compared to 4 & 0.827 \\
3 compared to 1 & 0.363 \\
4 compared to 1 & 0.587 \\
\hline
\end{tabular}

Category 2

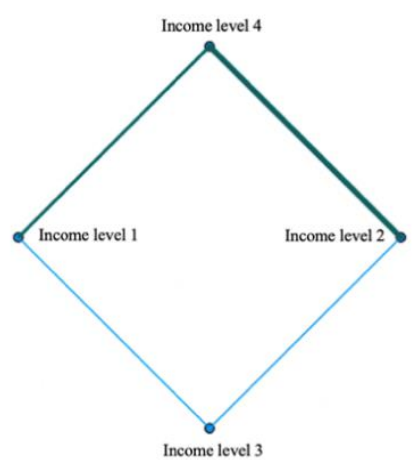

\begin{tabular}{lc}
\hline Sample 1-Sample 2 & Sig. \\
\hline 1 compared to 2 & 0.564 \\
1 compared to 3 & 0.005 \\
1 compared to 4 & 0.050 \\
2 compared to 3 & 0.007 \\
2 compared to 4 & 0.084 \\
3 compared to 4 & 0.531 \\
\hline
\end{tabular}

Figure 3. Pair comparisons between categories of Income levels in P38 =4, P38 = 1 and P38 = 2. Note: Each row tests the null hypothesis that the distributions in Sample 1 and Sample 2 are equal. Asymptotic meanings (bilateral tests) are displayed. The significance level is 0.050 .

- In the group of entrepreneurs without employees, differences occur among group 4-more than 1800 euros — on average of 8.06, with group 2-from 1 to 900 euros-on average 7.00 , with group 3 - from 901 to 1800 -on average 7.37 , and with group 1 -without income-on average 7.38. Employers without employees who are more affluent turn out to be the happiest.

- For the category of permanent employees, the differences are between group 2, on average 6.96, and groups 1 (average: 7.65), 3 (average: 7.49), and 4 (average: 7.48). Fixed earners with incomes from 1 to 900 euros seem to be the least happy.

- For the eventual employees, the differences are between group 4 (average 7.93) and group 1 (average: 6.85), and for group 3 (average: 7.64) with groups 1 and 2 (average: 7.03). Eventual earners who are richer seem to be the happiest.

Given these results, and the values of the means, the regressions, performed for the group of entrepreneurs without employees, indicate the following (Table 8):

- Comparison of income levels 4 and 2: Entrepreneurs without employees who earn more than 1800 euros per month are 6.452 times more likely to report that they feel pretty happy $(\mathrm{P} 6=7)$ to completely happy $(\mathrm{P} 6=10)$ than an incoming colleague with 1 to 900 euros would, and 4.310 times more likely to report feeling happy $(\mathrm{P} 6=8)$ to completely happy. In the second case, the specificity and sensitivity of the theoretical model balance are slightly more than in the other one, with a prediction level of $63.20 \%$.

- Comparison of income levels 4 and 3: People who earn more than 1800 euros are 2.421 times more likely to report being happy to completely happy than those earning from 900 to 1800 euros. Specificity and sensitivity are highly unbalanced, however.

- Comparison of income levels 4 and 1: People who earn more than 1800 euros are 3.425 times more likely to report being completely happy than those with no income. Specificity and sensitivity are pretty balanced, with a prediction level of $58.8 \%$. 
Table 7. Parameters for the relationship between perceived happiness and income level according to a professional situation.

\begin{tabular}{|c|c|c|c|c|c|c|c|c|}
\hline \multicolumn{9}{|c|}{ Category 3} \\
\hline & & P6 & $\mathrm{P} 41$ & & P6 & $\mathrm{P} 41$ & Kruskal-Wallis & $\begin{array}{c}\text { ANOVA } \\
\text { (Welch/Brown-Forsythe) }\end{array}$ \\
\hline \multirow{2}{*}{ P6 } & Spearman & 1 & 0.008 & Pearson & 1 & 0.036 & \multirow{2}{*}{$p=0.971$} & \multirow{2}{*}{$p=(0.810 / 0.667)$} \\
\hline & Sig. (bilat.) & & 0.942 & Sig. (bilat.) & & 0.739 & & \\
\hline \multicolumn{9}{|c|}{ Category 4} \\
\hline \multirow[t]{2}{*}{ P6 } & Spearman & 1 & $0.127 *$ & Pearson & 1 & 0.117 & Kruskal-Wallis & $\begin{array}{c}\text { ANOVA } \\
\text { (Welch/Brown-Forsythe) }\end{array}$ \\
\hline & Sig. (bilat.) & & 0.039 & Sig. (bilat.) & & 0.057 & $p=0.014$ & $p=(<0.001 / 0.008)$ \\
\hline \multicolumn{9}{|c|}{ Category 1} \\
\hline \multirow{2}{*}{ P6 } & Spearman & 1 & 0.035 & Pearson & 1 & 0.012 & Kruskal-Wallis & $\begin{array}{c}\text { ANOVA } \\
\text { (Welch/Brown-Forsythe) }\end{array}$ \\
\hline & Sig. (bilat.) & & 0.220 & Sig. (bilat.) & & 0.670 & $p=<0.001$ & $p=(<0.001 /<0.001)$ \\
\hline \multicolumn{9}{|c|}{ Category 2} \\
\hline \multirow{2}{*}{ P6 } & Spearman & 1 & $0.144^{* *}$ & Pearson & 1 & 0.163 ** & Kruskal-Wallis & $\begin{array}{c}\text { ANOVA } \\
\text { (Welch/Brown-Forsythe) }\end{array}$ \\
\hline & Sig. (bilat.) & & 0.001 & Sig. (bilat.) & & $<0.001$ & $p=0.007$ & $p=(<0.001 /<0.001)$ \\
\hline
\end{tabular}

Table 8. Relationship between perceived happiness and income level in the category of employers without employees $(\mathrm{P} 38=4)$.

Category 4

Comparison $\mathrm{P} 41=4$ con $\mathrm{P} 41=2$

\begin{tabular}{|c|c|c|c|c|c|c|}
\hline \multirow[b]{2}{*}{ Degree of Happiness } & \multirow[b]{2}{*}{ Sig. } & \multirow[b]{2}{*}{$\operatorname{Exp}(B)$} & \multicolumn{2}{|c|}{ Confidence Interval 95\% } & \multicolumn{2}{|c|}{ Value Forecast } \\
\hline & & & Inferior & Superior & $\begin{array}{c}\text { For P6 =0 } \\
\text { (specificity) }\end{array}$ & $\begin{array}{c}\text { For } 6=1 \\
\text { (sensibility) }\end{array}$ \\
\hline \multirow[b]{2}{*}{ Values between 7 and 10} & \multirow[b]{2}{*}{0.003} & \multirow[b]{2}{*}{6.452} & \multirow[b]{2}{*}{0.044} & \multirow[b]{2}{*}{0.540} & $0 \%$ & $100 \%$ \\
\hline & & & & & \multicolumn{2}{|c|}{$70.60 \%$} \\
\hline \multirow{2}{*}{ Values between 8 and 10} & \multirow[b]{2}{*}{$<0.001$} & \multirow{2}{*}{4.310} & \multirow{2}{*}{0.099} & \multirow{2}{*}{0.544} & $86.80 \%$ & $39.70 \%$ \\
\hline & & & & & \multicolumn{2}{|c|}{$63.20 \%$} \\
\hline \multicolumn{7}{|c|}{ Comparison $\mathrm{P} 41=4$ con $\mathrm{P} 41=3$} \\
\hline \multirow{2}{*}{ Values between 8 and 10} & \multirow[b]{2}{*}{0.024} & \multirow[b]{2}{*}{2.421} & \multirow{2}{*}{0.192} & \multirow[b]{2}{*}{0.890} & $0 \%$ & $100 \%$ \\
\hline & & & & & \multicolumn{2}{|c|}{$56.20 \%$} \\
\hline \multicolumn{7}{|c|}{ Comparison $\mathrm{P} 41=4$ con $\mathrm{P} 41=1$} \\
\hline \multirow{2}{*}{ Values between 8 and 10} & \multirow{2}{*}{0.008} & \multirow{2}{*}{3.425} & \multirow{2}{*}{0.118} & \multirow{2}{*}{0.724} & $68.9 \%$ & $48.9 \%$ \\
\hline & & & & & \multicolumn{2}{|c|}{$58.8 \%$} \\
\hline
\end{tabular}

\section{Discussion and Conclusions}

Regardless of their professional status, all respondents are happy, as their averages are above a P6 value of 7. Of these, the two employers (with and without employees) are the happiest for all levels, from P6 $=6$. However, the sample shows an association between professional status and the degree of happiness perceived; hypothesis $\mathrm{H}_{1}$ is supported.

When analyzing in detail which categories differ statistically significantly in terms of their means, it is concluded that there are differences between the category of entrepreneurs with employees and the other categories. That is, employers with employees seem to feel happier than the rest of the professional categories. The distance appears to be more 
significant for the group of temporary employees. The differences are most relevant between those who expressly declare themselves completely happy.

Therefore, we can confirm that entrepreneurs with employees are more likely to report being happy than those in other groups; thus, hypothesis $\mathrm{H}_{2.1}$ is supported.

When the study focuses on the group of entrepreneurs and introduces sociodemographic variables, we discover that the gender variable does not influence whether an entrepreneur with employees feels happy, nor in the group of permanent employees. It is an association with gender for the group of professionals and self-employed without employees and temporary employees, with men reporting that they are happier than women. For the eventual employees, with women happier than men [88], the hypothesis $\mathrm{H}_{1 \mathrm{EmpSex}}$ is supported, but only for entrepreneurs without employees [89].

When levels of study analyze happiness, it can be seen that there is no relationship between these two variables in either group of employers, with or without employees. It does exist for employees with high intensity (error of less than $0.1 \%$ ). In the case of permanent employees, those with first-level university studies seem to be the happiest. However, the most comfortable temporary employees seem to be those with second-level university studies (postgraduate). In both cases, the differences in perceived happiness are incredibly intense among employees with qualification levels up to primary level, who seem to be the least happy of all [55]. Therefore, in the case of employers, the hypothesis H1EmpStudy is rejected.

When the relationship between happiness and income level is studied, the two groups of employees, with error levels of less than $0.1 \%$, and employers without employees, with an error very close to $1 \%$, are confirmed [90]. In this last group, that of professionals or self-employed persons without employees, it is clear that the H1EmpInc hypothesis is admitted. Those who earn most are the happiest, and this difference is especially shown against those who earn up to 900 euros.

In none of the cases with significant differences between some categories do those who receive the minor income receive the greatest happiness.

For the employers' group with employees, the results are consistent with what is established by the literature [91]. While, for the rest of the professional groups, sociodemographic and economic variables have been related to happiness, this has not been the case for employers' groups with employees.

A notable increase in monetary income does not necessarily mean greater happiness or subjective well-being in people after obtaining a certain income level [92-94].

While for the rest of the professional groups, sociodemographic and economic variables have been related to happiness, this has not been the case for employers with employees. However, belonging to this group is associated with greater happiness, which would lead us to think that employers with employees are happier just because they are in this group, regardless of gender, education level, or income [95]. Moreover, given that some of these variables change employers' happiness without employees, could it be generating employment that makes this group happier? This question is supported by the literature $[96,97]$.

Our research has certain limitations. The main one is the small number of members of the entrepreneur categories, especially that of entrepreneurs with employees, compared to earners groups.

Another one was mentioned at the beginning of this investigation: very few scientific studies empirically examine Spain's happiness/entrepreneurship construct. This academic phenomenon does not occur in other advanced countries such as Germany, Netherlands, Sweden, or the United States [98,99]. An essential body of literature analyzes the influence of sociodemographic factors on entrepreneurs' happiness in the latter country. These empirical studies arrive at causal relationships similar to those presented on these pages $[10,100]$. It should also be noted that our findings show a notable theoretical consistency with the literature consulted for the development of this study. In this sense, it can be affirmed that this work can have interesting practical implications for implementing policies that con- 
sider the happiness of Spanish entrepreneurs a differential strategic factor that motivates innovation, intra-entrepreneurship, creativity, etc. [59,101].

Another limitation is that in the analyses carried out in this work using linear logistic regressions, the specificities and sensitivities of the theoretical prediction model are usually extreme, in pairs of $0-100 \%$, except in particular cases where they are less unbalanced. When the groups or categories of the variable P38 are analyzed and within each group the categories of the sociodemographic variables are studied, the number of records, $\mathrm{N}$, decreases, which significantly reduces reliability. Following Freeman's minimum sample size formula [102], this problem is fixed in most cases treated since $\mathrm{N}$ is greater than $10+1$ (10 times the number of independent variables, or predictors, studied in each logistic regression plus one). According to Peruzzi's formula [103], for the number of statistical events (those that acquire a value of 1 in regression in the variable), the value must be at least ten times the number of predictor variables; this requirement is fulfilled in the calculations.

Another limitation is that this is a longitudinal study, but in different months of the same year, since the perception of happiness was not asked again in the barometers after 2018. It can limit the results, and any conclusions reached. It cannot be forgotten that the experimental analysis of entrepreneurial happiness is a cumulative process that occurs over time, especially when exploring the influence of sociodemographic, cultural, and economic factors on the happiness of entrepreneurs or self-employed people [104]. The continuation of this study will entail academic investigations with a longer temporal horizon. The authors propose creating a specific database with more records for the categories of entrepreneurs and repeating it in the same period for several years. Doing so will make it possible to more precisely investigate the effects of the variables cited above on the individual happiness of these certain economic actors.

Based on what has been previously stated, it would be appropriate for future work to explore the moderating (interaction) and mediating effects of the variables related to the group of entrepreneurs and self-employed people, such as the degree of satisfaction with their personal economic situation. For example, a study could consider the relationship between economic income and happiness or the possible relationship between the economic situation and happiness [105]. It will be necessary to analyze whether any of the variables mentioned, the sociodemographic variables with which we have worked, or others, had an uncertain impact on the results. Therefore, advances in this field of research will allow us to better understand the critical role that the intangible resource of happiness has on people when they decide to become entrepreneurs or self-employed in the era of Industry 4.0 in the future [106,107]. It is even more interesting in the post-COVID19 era.

Notwithstanding the preceding limitations, this study allows us to have a better understanding of the objective pursued: to analyze the degree of happiness perceived by Spanish entrepreneurs (with or without employees), compared to that perceived by employees (permanent or temporary), and measure whether that happiness is associated with certain sociodemographic variables (sex, level of studies and income level). It, in turn, makes it possible to help fill the research gap that exists in the literature on this type of study.

Author Contributions: Conceptualization, R.R.-R., M.-J.F.-R., E.A.-T. and L.B.T.-P.; methodology, R.R.-R., M.-J.F.-R., E.A.-T. and L.B.T.-P.; software, M.-J.F.-R.; validation, R.R.-R. and M.-J.F.-R.; formal analysis, R.R.-R. and M.-J.F.-R.; investigation, R.R.-R., M.-J.F.-R., E.A.-T. and L.B.T.-P.; resources, R.R.-R., M.-J.F.-R., E.A.-T. and L.B.T.-P.; Data curation, M.-J.F.-R.; writing-original draft preparation, R.R.-R., M.-J.F.-R., E.A.-T. and L.B.T.-P.; writing-review and editing, R.R.-R., M.-J.F.-R., E.A.-T. and L.B.T.-P.; visualization, R.R.-R., M.-J.F.-R., E.A.-T. and L.B.T.-P.; supervision, R.R.-R. and M.-J.F.-R.; project administration, R.R.-R., M.-J.F.-R., E.A.-T. and L.B.T.-P. All authors have read and agreed to the published version of the manuscript.

Funding: This research received no external funding.

Institutional Review Board Statement: Not applicable. 
Informed Consent Statement: Not applicable.

Acknowledgments: This research is part of the results of the research project Happiness Management, creativity and well-being in the era of Industry 4.0 from the perspective of social sciences and humanities of the Universidad PolitécnicaSalesiana de Ecuador.

Conflicts of Interest: The authors declare no conflict of interest.

\section{References}

1. Abreu, M.; Oner, O.; Brouwer, A.; Van Leeuwen, E. Well-being effects of self-employment: A spatial inquiry. J. Bus. Ventur. 2019, 34, 589-607. [CrossRef]

2. Sorgner, M.; Sorgner, A.; Wyrwich, M. Self-employment and well-being across institutional contexts. J. Bus. Ventur. 2019, 34, 105946. [CrossRef]

3. Gopinath, N.; Mitra, J. Entrepreneurship and well-being: Towards developing a novel conceptual framework for entrepreneurial sustainability in organisations. J. Entrep. Innov. Emerg. Econ. 2017, 3, 62-70. [CrossRef]

4. Sevä, I.J.; Vinberg, S.; Nordenmark, M.; Strandh, M. Subjective well-being among the self-employed in Europe: Macroeconomy, gender and immigrant status. Small Bus. 2016, 46, 239-253. [CrossRef]

5. Salas-Vallina, A.; Alegre, J.; Guerrero, R.F. Happiness at work in knowledge-intensive contexts: Opening the research agenda. Eur. Res. Manag. Bus. Econ. 2018, 24, 149-159. [CrossRef]

6. Florida, R.; Mellander, C.; Rentfrow, P.J. The happiness of cities. Reg. Stud. 2013, 47, 613-627. [CrossRef]

7. Ball, R.; Chernova, K. Absolute income, relative income, and happiness. Soc. Indic. Res. 2008, 88, 497-529. [CrossRef]

8. Tsou, M.W.; Liu, J.T. Happiness and domain satisfaction in Taiwan. J. Happiness Stud. 2001, 2, 269-288. [CrossRef]

9. Ravina-Ripoll, R.; Núñez-Barriopedro, E.; Evans, R.D.; Ahumada-Tello, E. Employee Happiness in the Industry 4.0 Era: Insights from the Spanish Industrial Sector. In Proceedings of the Technology \& Engineering Management Conference (TEMSCON), 2019 International Conference (IEEE), Atlanta, GA, USA, 12-14 June 2019; IEEE: New York, NY, USA, 2019. [CrossRef]

10. Hmieleski, K.M.; Sheppard, L.D. The Yin and Yang of entrepreneurship: Gender differences in the importance of communal and agentic characteristics for entrepreneurs' subjective well-being and performance. J. Bus. Ventur. 2019, 34, 709-730. [CrossRef]

11. Kibler, E.; Wincent, J.; Kautonen, T.; Cacciotti, G.; Obschonka, M. Can prosocial motivation harm entrepreneurs' subjective well-being? J. Bus. Ventur. 2019, 34, 608-624. [CrossRef]

12. Stephan, U. Entrepreneurs' mental health and well-being: A review and research agenda. Acad. Manag. Perspect. 2018, 32, $290-322$. [CrossRef]

13. Neto, R.D.C.A.; Rodrigues, V.P.; Panzer, S. Exploring the relationship between entrepreneurial behavior and teachers' job satisfaction. Teach. Teach. Educ. 2017, 63, 254-262. [CrossRef]

14. Andersson, P. Happiness and health: Well-being among the self-employed. J. Socio-Econ. 2008, 37, 213-236. [CrossRef]

15. Audretsch, D.B.; Belitski, M. Entrepreneurial ecosystems in cities: Establishing the framework conditions. J. Technol. Transf. 2017, 42, 1030-1051. [CrossRef]

16. Arniati, T.; Puspita, D.A.; Amin, A.; Pirzada, K. The implementation of good corporate governance model and auditor independence in earnings' quality improvement. Entrep. Sustain. Issues 2019, 7, 188-200. [CrossRef]

17. Eridani, R.; Pirzada, K.; Kurniawan, M.K. The role of auditor characteristics: Earnings management and audit committee effectiveness. Entrep. Sustain. Issues 2020, 7, 3242-3252. [CrossRef]

18. Nosara, F.; Pirzada, K.; Lestari, T.; Cahyono, R. Impact of demographic factors on risk tolerance. J. Secure. Sustain. Issues 2020, 9 , 1265-1273. [CrossRef]

19. Rudyanto, A.; Pirzada, K. The role of sustainability reporting in shareholder perception of tax avoidance. Soc. Responsib. J. 2020. [CrossRef]

20. Observatorio del Emprendimiento de España. Global Entrepreneurship Monitor. Informe GEM España 2020-2021; Ed. Universidad de Cantabria: Santander, Spain, 2021.

21. Ravina-Ripoll, R.; Marchena-Domínguez, J.; Tobar-Pesantez, L. (Eds.) Happiness Management: A Lighthouse for Social Wellbeing, Creativity and Sustainability; Editorial Peter Lang: Bern, Switzerland, 2021.

22. Markussen, T.; Fibæk, M.; Tarp, F.; Tuan, N.D.A. The happy farmer: Self-employment and subjective well-being in rural Vietnam. J. Happiness Stud. 2018, 19, 1613-1636. [CrossRef]

23. Gallardo-Vázquez, D.; Pajuelo-Moreno, M.L. Entrepreneurship: Concepts, Methodologies, Tools, and Applications; I.G.I. Global: Hershey, PA, USA, 2017.

24. Zampetakis, L.A.; Kafetsios, K.; Lerakis, M.; Moustakis, V.S. An emotional experience of entrepreneurship: Self-construal, emotion regulation, and expressions to anticipatory emotions. J. Career Dev. 2017, 44, 144-158. [CrossRef]

25. Swan, C.D.; Morgan, D. Who wants to be an eco-entrepreneur? Identifying entrepreneurial types and practices in ecotourism businesses. Int. J. Entrep. Innov. 2016, 17, 120-132. [CrossRef]

26. Peredo, A.M.; McLean, M. Social entrepreneurship: A critical review of the concept. J. World Bus. 2006, 41, 56-65. [CrossRef]

27. Ryff, C.D. Entrepreneurship and eudaimonic well-being: Five venues for new science. J. Bus. Ventur. 2019, 34, 646-663. [CrossRef] [PubMed] 
28. Wiklund, J.; Nikolaev, B.; Shir, N.; Foo, M.D.; Bradley, S. Entrepreneurship and well-being: Past, present, and future. J. Bus. Ventur. 2019, 34, 579-588. [CrossRef]

29. Naudé, W.; Amorós, J.E.; Cristi, O. 'Surfeiting, the appetite may sicken': Entrepreneurship and happiness. Small Bus. Econ. 2014, 42, 523-540. [CrossRef]

30. Gries, T.; Naudé, W.A. Entrepreneurship and Structural Economic Transformation. Small Bus Econ. 2010, 34, 1. [CrossRef]

31. Van der Loos, M.J.H.; Koellinger, P.D.; Groenen, P.J.F.; Thurik, A.R. Genome-wide association studies and the genetic of entrepreneurship. Eur. J. Epidemiol. 2010, 25, 1-3. [CrossRef]

32. Pham, T.; Talavera, O.; Zhang, M. Self-employment, financial development, and well-being: Evidence from China, Russia, and Ukraine. J. Comp. Econ. 2018, 46, 754-769. [CrossRef]

33. Bradley, D.E.; Roberts, J.A. Self-employment and job satisfaction: Investigating the role of self-efficacy, depression, and seniority. J. Small Bus. Manag. 2004, 42, 37-58. [CrossRef]

34. Cooper, A.C.; Artz, K.W. Determinants of satisfaction for entrepreneurs. J. Bus. Ventur. 1995, 10, 439-457. [CrossRef]

35. Susanto, Y.K.; Pirzada, K.; Adrianne, S. Is tax aggressiveness an indicator of earnings management? Polish J. Manag. Stud. 2019, 20, 516-527. [CrossRef]

36. Bencsik, P.; Chuluun, T. Comparative well-being of the self-employed and paid employees in the USA. Small Bus. Econ. 2021, 56, 355-384. [CrossRef]

37. Binder, M.; Coad, A. How satisfied are the self-employed? A life domain view. J. Happiness Stud. 2016, 17, 1409-1433. [CrossRef]

38. Dijkhuizen, J.; Veldhoven, M.V.; Schalk, R. Four types of well-being among entrepreneurs and their relationships with business performance. J. Bus. Entrep. 2016, 25, 184-210. [CrossRef]

39. Pirzada, K. Risk management, sustainable governance impact on corporate performance. J. Secur. Sustain. Issues 2020, 9, 993-1004. [CrossRef]

40. Wait, L.N.; Primiana, H.I.; Pirzada, K.; Sudarsono, R. Political connection, blockholder ownership and performance. Entrep. Sustain. Issues 2019, 7, 52-68. [CrossRef]

41. Yacoub, Y.; Lestari, N. Flypaper effect in Indonesia: The case of Kalimantan. J. Fin. Bank. Rev. 2019, 4, 116-121. [CrossRef]

42. Núñez-Barriopedro, E.; Cuesta-Valiño, P.; Gutiérrez-Rodríguez, P.; Ravina-Ripoll, R. How does happiness influence the loyalty of karate athletes? A model of structural equations from the constructs: Consumer satisfaction, engagement, and meaningful. Front. Psychol. 2021, 12, 794. [CrossRef]

43. Huang, J. Income inequality, distributive justice beliefs, and happiness in China: Evidence from a nationwide survey. Soc. Indic. Res. 2019, 142, 83-105. [CrossRef]

44. Lawrence, E.M.; Rogers, R.G.; Zajacova, A.; Wadsworth, T. Marital happiness, marital status, health, and longevity. J. Happiness Stud. 2019, 20, 1539-1561. [CrossRef]

45. Botha, F.; Wouters, E.; Booysen, F. Happiness, socioeconomic status, and family functioning in South African households: A structural equation modelling approach. Appl. Res. Qual. Life 2018, 13, 947-989. [CrossRef]

46. Frey, B.S.; Stutzer, A. Economics of Happiness; Springer International Publishing: Cham, Switzerland, 2018.

47. Lelo, K.; Monni, S.; Tomassi, F. Urban inequalities in Italy: A comparison between Rome, Milan and Naples. Entrep. Sustain. Issues 2018, 6, 939-957. [CrossRef]

48. Pritvorova, T.; Temirbyeva, D.; Petrenko, Y.; Benčič, S. Income distribution peculiarities of households with children: A case study. Entrep. Sustain. Issues 2020, 7, 2924-2939. [CrossRef]

49. Vasconcelos, V.V. Social justice and sustainable regional development: Reflections on discourse and practice in public policies and public budget. Insights Into Reg. Dev. 2021, 3, 10-28. [CrossRef]

50. Suryani, A.; Pirzada, K. Analysis of opportunistic behavior of management to company performance. Polish J. Manag. Stud. 2018, 18, 379-388. [CrossRef]

51. Iceland, J.; Ludwig-Dehm, S. Black-white differences in happiness, 1972-2014. Soc. Sci. Res. 2019, 77, 16-29. [CrossRef]

52. Hori, M.; Kamo, Y. Gender differences in happiness: The effects of marriage, social roles, and social support in East Asia. Appl. Res. Qual. Life 2018, 13, 839-857. [CrossRef]

53. Gudmundsdottir, D.G. The impact of economic crisis on happiness. Soc. Indic. Res. 2013, 110, 1083-1101. [CrossRef]

54. Thandabhani, M. Strategic communication for women entrepreneurs: A case study of India. Insights Into Reg. Dev. 2020, 2, 480-497. [CrossRef]

55. Nikolaev, B. Does higher education increase hedonic and eudaimonic happiness? J. Happiness Stud. 2018, 19, 483-504. [CrossRef]

56. Cuñado, J.; De Gracia, F.P. Environment and happiness: New evidence for Spain. Soc. Indic. Res. 2013, 112, 549-567. [CrossRef]

57. Argyle, M. Causes and correlates of happiness. In Well-Being: The Foundations of Hedonic Psychology; Kahneman, D., Diener, E., Schwarz, N., Eds.; Russell Sage Foundation: New York, NY, USA, 2013; pp. 353-373.

58. Ferranti, F.; Karmudiandri, A. Corporate governance and financial ratios effect on audit report Lag. Acc. Fin. Rev. 2020, 5, 15-21. [CrossRef]

59. Ravina-Ripoll, R.; Tobar-Pesantez, L.B.; Galiano-Coronil, A.; Marchena-Domínguez, J. (Eds.) Happiness Management and Social Marketing: A Wave of Sustainability and Creativity; Editorial Peter Lang: Bern, Switzerland, 2021. [CrossRef]

60. Sasongko, G.; Huruta, A.D.; Pirzada, K. Why labor force participation rate rises? New empirical evidence from Indonesia. Entrep. Sustain. Issues 2019, 7, 166-176. [CrossRef] 
61. Albert, J.F.; Casado-Díaz, J.M.; Simón, H. The commuting behaviour of self-employed workers: Evidence for Spain. Pap. Reg. Sci. 2019, 98, 2455-2477. [CrossRef]

62. Orrego, C. La dimensión humana del emprendimiento. Rev. Cienc. Estratégicas 2008, 16, 225-236.

63. Anger-Egg, E. Técnicas de Investigación Social; Editorial Lumen: Buenos Aires, Argentina, 1995.

64. Princes, E.; Manurung, A.H. Taking advantage of social conformity in entrepreneurship. J. Manag. Mark. Rev. 2020, 5, 64-73. [CrossRef]

65. Barón, R.M.; Kenny, D.A. The moderator-mediator variable distinction in social psychological research: Conceptual, strategic, and statistical considerations. J. Personal. Soc. Psychol. 1986, 51, 1173-1182. [CrossRef] [PubMed]

66. Hendrawan, R.; Nugroho, K.W.A.; Permana, G.T. Efficiency perspective on telecom mobile data traffic. J. Bus. Econ. Rev. 2020, 5, 38-44. [CrossRef]

67. Setiawan, A.; Dalimunthe, Z.; Rizkianto, E. Bankruptcy risk among indonesian stock exchange listed companies. J. Fin. Bank. Rev. 2019, 4, 122-127. [CrossRef]

68. Pirzada, K.; Mustapha, M.Z.; Alfan, E. The role of nomination committee in selecting female directors: A Case of Malaysia. Pertanika J. Soc. Sci. Humanit. 2016, 24, 105-118.

69. Yanos, M.H.A.; Leal, R.C. Mungbean (Vignaradiata) as a source of income among farmers. J. Bus. Econ. Rev. 2020, 5, 10-17. [CrossRef]

70. Ferdian, A.; Luturlean, B.S.; Zhafira, K.D.; Izumi, N.K. The impact of work stress on turnover intention in Indonesia: Is there a mediation from employee' job satisfaction? Ferdian 2020, 5, 31-40. [CrossRef]

71. Alexander, N. The effect of ownership structure, cash holding and tax avoidance on income smoothing. J. Fin. Bank. Rev. 2019, 4, 128-134. [CrossRef]

72. Mokhtar, K.S.; Rahman, N.A.; Haron, M.S. Complying with the United Nations' Sustainable Development Goals: A case of the Malaysian ageing population. Glob. J. Bus. Soc. Sci. Rev. 2020, 8, 1-11. [CrossRef]

73. Garnasih, R.L.; Kurniawaty, K.; Suryatiningsih, D. Determinants of culinary business performance. J. Bus. Econ. Rev. 2020, 5, 1-9. [CrossRef]

74. Pirzada, K.; Mustapha, M.Z.; Alfan, E.B. Antecedents of ethnic diversity: The role of nomination committees. Int. J. Econ. Manag. 2017, 11, 103-119. [CrossRef]

75. Mora, R.P. Assessing the attitudes, aspirations, and gender differences of pre-service mathematics teachers. J. Bus. Econ. Rev. 2020, 5, 18-27. [CrossRef]

76. Solikhah, B.; Della Firmansyah, N.; Pirzada, K. The influence of effective B.O.C. on choice of auditor. Pertanika J. Soc. Sci. Humanit. 2017, 25, 271-280.

77. Pirzada, K. Providers and users' perception of voluntary need of human resource disclosure: A content analysis. Polish J. Manag. Stud. 2016, 14, 232-242. [CrossRef]

78. Sulistiowati; Komari, N. Achieve Model on Research and Publication Performance. Glob. J. Bus. Soc. Sci. Rev. 2020, 8, 22-29. [CrossRef]

79. Francisco, I.F.S.; Castano, M.C.N. The impact of career adaptability to the job search strategies of graduate students in N.C.R. Fr. IFS 2020, 5, 41-50. [CrossRef]

80. Pradipta, A.; Zalukhu, A.G. Audit report lag: Specialized auditor and corporate governance. Glob. J. Bus. Soc. Sci. Rev. 2020, 8 , 41-48. [CrossRef]

81. Ward, J.G.; Ward, Y.D.; Jones, S. Journaling to develop a study abroad course for business majors. Glob. J. Bus. Soc. Sci. Rev. 2020, 8, 30-40. [CrossRef]

82. Djashan, I.A.; Agustinus, Y. The effect of firm size, profitability, audit committee, and other factors to firm value. Acc. Fin. Rev. 2020, 5, 22-27. [CrossRef]

83. Saragih, R.; Prasetio, A.P. Effective human resources practice and employee engagement: The Mediating roles of organizational support. J. Manag. Mark. Rev. 2020, 5, 74-83. [CrossRef]

84. Hanif, H.; Rakhman, A.; Nurkholis, M.; Pirzada, K. Intellectual capital: Extended VAIC model and building of a new HCE concept: The case of Padang Restaurant Indonesia. Afr. J. Hosp. Tour. Leis. 2019, 8, 1-15.

85. Wahyuni, N.M.; Astawa, I.P. An integrative model of market orientation on innovation performance. J. Manag. Mark. Rev. 2020, 5, 51-63. [CrossRef]

86. Hendrayati, H.; Askolani, A.; Sudrajat, C.T.; Syahidah, R.K. E-service quality and price to build online transportation loyalty in Indonesia. J. Manag. Mark. Rev. 2020, 5, 16-30. [CrossRef]

87. Ristyawan, M.R. An integrated artificial intelligence and resource base view model for creating competitive advantage. J. Bus. Econ. Rev. 2020, 5, 28-37. [CrossRef]

88. Sweida, G.; Sherman, C.L. Does happiness launch more businesses? Affect, gender, and entrepreneurial intention. Int. J. Environ. Res. Public Health 2020, 7, 6908. [CrossRef]

89. Lubis, A.; Dalimunthe, R.; Absah, Y.; Fawzeea, B.K. The influence of customer relationship management (CRM) indicators on customer loyalty of sharia based banking system. J. Manag. Mark. Rev. 2020, 5, 84-92. [CrossRef]

90. Asmara, A.Y.; Rahayu, A.Y.S. Innovation in delivering public health service: Practice in banyuwangi regency-Indonesia. Glob. J. Bus. Soc. Sci. Rev. 2020, 8, 12-21. [CrossRef] 
91. Ravina-Ripoll, R.; Foncubierta-Rodríguez, M.J.; Ahumada-Tello, E.; Evans, R.D. Does Money Makes Entrepreneurs Happy in the Age of Industries 4.0? In Proceedings of the Technology \& Engineering Management Conference (TEMSCON), 2020 International Conference (IEEE), Novi, MI, USA, 3-6 June 2020. [CrossRef]

92. Kollamparambil, U. Happiness, happiness inequality and income dynamics in South Africa. J. Happiness Stud. 2019, 21, 201-222. [CrossRef]

93. Ng, W.; Diener, E. Affluence and subjective well-being: Does income inequality moderate their associations? Appl. Res. Qual. Life 2019, 14, 155-170. [CrossRef]

94. Deaton, A.; Stone, A.A. Two happiness puzzles. Am. Econ. Rev. 2013, 103, 591-597. [CrossRef]

95. Sappleton, N.; Lourenço, F. Work satisfaction of the self-employed: The roles of work autonomy, working hours, gender and sector of self-employment. Int. J. Entrep. Innov. 2016, 17, 89-99. [CrossRef]

96. Brieger, S.A.; Gielnik, M.M. Understanding the gender gap in immigrant entrepreneurship: A multi-country study of immigrants' embeddedness in economic, social, and institutional contexts. Small Bus. Econ. 2021, 56, 1007-1031. [CrossRef]

97. Berglund, V.; Johansson Sevä, I.; Strandh, M. Subjective well-being and job satisfaction among self-employed and regular em-ployees: Does personality matter differently? J. Small Bus. 2016, 28, 55-73. [CrossRef]

98. Carree, M.A.; Verheul, I. What makes entrepreneurs happy? Determinants of satisfaction among founders. J. Happiness Stud. 2012, 13, 371-387. [CrossRef]

99. Scarpello, V.; Carraher, S.M. Are pay satisfaction and pay fairness the same construct? A cross-country examination among the self-employed in Latvia, Germany, the UK, and the USA. Balt. J. Manag. 2008, 3, 23-39. [CrossRef]

100. Ravina-Ripoll, R.; Tobar-Pesantez, L.; López-Sanchez, J.A. Entrepreneur happiness as a portfolio of competitiveness and sustainability in the Covid-19 era. Int. J. Entrep. 2021, 25, 1-3.

101. Foncubierta-Rodríguez, M.J.; Ravina-Ripoll, R.; Ahumada-Tello, E.; Tobar-Pesantez, L.B. Are Spanish public employees happier in their work performance in the Industry 4.0 era? Polish J. Manag. Stud. 2020, 22, 103-116. [CrossRef]

102. Freeman, D.H. Applied Categorical Data Analysis; Marcel Dekker Inc.: New York, NY, USA, 1987. [CrossRef]

103. Peruzzi, P.; Concato, J.; Kemper, E.; Holford, T.R.; Feinstein, A.R. A simulation study of the number of events per variable in logistic regression analysis. J. Clin. Epidemiol. 1996, 49, 1373-1379. [CrossRef]

104. Mehjabeen, M.; Bukth, T. Comparative analysis of the dominant themes in C.S.R. reporting discourse in Bangladesh: A structured literature review. Acc. Fin. Rev. 2020, 5, 1-14. [CrossRef]

105. Baron, I.S.M.; Agustina, H. The role of psychological testing as an effort to improve employee competency. J. Manag. Mark. Rev. 2020, 5, 1-15. [CrossRef]

106. Ravina-Ripoll, R.; Foncubierta-Rodríguez, M.J.; Ahumada-Tello, E.; Evans, R.D. The role of religion and marital status in happiness perception of Spanish Entrepreneurs. A concept to be explore in the Post COVID-19 era. In Proceedings of the Technology \& Engineering Management Conference-Europe (TEMSCON-EUR), Dubrovnik, Croatia, 17-20 May 2021. [CrossRef]

107. Ravina-Ripoll, R.; Foncubierta-Rodríguez, M.J.; López-Sánchez, J.A. Certification happiness management: An integral instrument for human resources management in post-COVID-19 era. Int. J. Bus. Environ. 2021, 12, 287-299. [CrossRef] 